Review

\title{
War and Peas: Molecular Bases of Resistance to Powdery Mildew in Pea (Pisum sativum L.) and Other Legumes
}

\author{
Anton S. Sulima *(D) and Vladimir A. Zhukov (D)
}

Citation: Sulima, A.S.; Zhukov, V.A War and Peas: Molecular Bases of Resistance to Powdery Mildew in Pea (Pisum sativum L.) and Other Legumes. Plants 2022, 11, 339. https://doi.org/10.3390/ plants11030339

Academic Editors: Nina Mironenko and Igor Maksimov

Received: 10 December 2021

Accepted: 25 January 2022

Published: 27 January 2022

Publisher's Note: MDPI stays neutral with regard to jurisdictional claims in published maps and institutional affiliations.

Copyright: (C) 2022 by the authors. Licensee MDPI, Basel, Switzerland. This article is an open access article distributed under the terms and conditions of the Creative Commons Attribution (CC BY) license (https:// creativecommons.org/licenses/by/ $4.0 /)$.
All-Russia Research Institute for Agricultural Microbiology (ARRIAM), Laboratory of Genetics of Plant-Microbe Interactions, Podbelsky Sh. 3, 196608 Saint-Petersburg, Russia; vzhukov@arriam.ru

* Correspondence: ASulima@arriam.ru

\begin{abstract}
Grain legumes, or pulses, have many beneficial properties that make them potentially attractive to agriculture. However, the large-scale cultivation of legumes faces a number of difficulties, in particular the vulnerability of the currently available cultivars to various diseases that significantly impair yields and seed quality. One of the most dangerous legume pathogens is powdery mildew (a common name for parasitic fungi of the order Erisyphales). This review examines the methods of controlling powdery mildew that are used in modern practice, including fungicides and biological agents. Special attention is paid to the plant genetic mechanisms of resistance, which are the most durable, universal and environmentally friendly. The most studied legume plant in this regard is the garden pea (Pisum sativum L.), which possesses naturally occurring resistance conferred by mutations in the gene MLO1 (Er1), for which we list here all the known resistant alleles, including er1-12 discovered by the authors of this review. Recent achievements in the genetics of resistance to powdery mildew in other legumes and prospects for the introduction of this resistance into other agriculturally important legume species are also discussed.
\end{abstract}

Keywords: powdery mildew; Fabaceae; Pisum sativum; MLO gene family; er1

\section{Introduction}

Legumes (Fabaceae) are the third largest land-plant family, accounting for about $7 \%$ of flowering plant species [1]. Grain legumes, or pulses, have long been an important human and animal food source, providing protein, carbohydrates, and fiber [2]. Moreover, they are known for their ability to consume atmospheric nitrogen through symbiosis with rhizobia [3], leading to an increase in soil fertility that enables a reduction in the use of chemical nitrogen fertilizers, which significantly contribute to the greenhouse effect [4]. Despite this, domesticated legumes still occupy a minimal part of arable land, which is mostly dominated by cereal crops; soybeans, the most cultivated legume in the world, are still far below the major cereals (e.g., rice, wheat, maize) [5]. As the ever-growing human population faces global challenges such as the risk of climate change and the increasing demand for food and energy, the usage of environmentally friendly pulse crops has become more and more prominent, though still not equally worldwide. While the introduction of legumes into agricultural systems can, among others, reduce the risks of monoculture, disrupt pathogens' life cycles and promote soil biodiversity; the benefits of such crop diversification do not often deliver immediate and/or apparent financial profits. In addition, pulse crops, having been neglected en masse for a long time, are currently inferior to cereals in terms of the quantity and quality of the available cultivars, and their genetic resources remain largely unexplored and unexploited $[2,6,7]$. These include the resistance to their own pathogens and pests [8,9], among which one of the most notorious and dangerous are the so-called powdery mildews, a group of parasitic fungi from the order Erysiphales [10-12]. Under suitable conditions, powdery mildew is able to cause up to a $50 \%$ loss in the yield of legumes such peas or soybeans [13]. In this review, we discuss 
the chemical and biological methods of controlling powdery mildew, examine the natural resistance to powdery mildew in the important crop legumes, especially in the garden pea (Pisum sativum L.) as the main and best-studied example of natural mlo1-based recessively inherited resistance [14,15], and list the main advances that have been made in studying and applying the molecular-genetic bases of this type of host-parasite interaction.

\section{Know Your Enemy}

\subsection{The Causative Agent of Powdery-Mildew Disease}

Powdery mildews are ascomycete fungi of the order Erysiphales (family Erysiphaceae). They are obligate biotrophs of worldwide distribution, presently including 16 genera with approximately 900 species [16,17]. All are parasites of vascular plants, predominantly dicotyledons, of which they can infect about 10,000 species [12,16,17]. Unlike most plant pathogen fungi, which grow within plant tissue, powdery mildews live mostly epiphytically, forming mats and fields of whitish hyphae on almost any plant organ. While different powdery mildews have been used to study key aspects of host-parasite interactions, developmental morphology, cytology, and molecular biology [18-23], there are still many unanswered questions, as recent research has shown that the biology of powdery mildews is more complex than previously realized, and their systematics still undergo major revisions [24-27].

The life cycle of powdery mildew can involve both sexual and asexual stages (teleomorph and anamorph, respectively), or lack either of them [28,29]; in some species, the teleomorphic stage develops depending on weather conditions, namely the level of moisture $[12,30]$. Life cycles are usually synchronized with those of the host plants, so in order to prevent or control the disease, an understanding of how a particular host-pathogen system functions in a particular environment is required [31].

There are three main stages in the powdery-mildew life cycle: infection, reproduction and perennation (wintering) (Figure 1). An infection is initiated when an ascospore or conidium lands on a susceptible host and germinates to form a hypha with appressoria, which are short, lateral hyphal outgrowths or swellings producing penetration pegs to infect the host [32-34]. Plants can interrupt the germination of spores with so-called prepenetration defense mechanisms $[9,35]$. These mechanisms remain poorly understood, but it is known that the physical structure and chemical composition of the host surface, especially of epicuticular leaf waxes, suppress the germination and appressoria formation of powdery mildew [36,37].

Penetration pegs formed by appressoria are narrow protrusions that pierce the walls of host cells. The haustorium is an extension of the penetration peg within the host cell that serves as an interface between parasite and host, causing the plant to divert nutrients to the fungus [32]. The most efficient and well-known resistance mechanisms against powdery mildews are those that efficiently impede the penetration peg to breach plant cell wall $[38,39]$. These mechanisms provide durable and broad-spectrum resistance to biotrophic pathogens including powdery mildew, which are usually associated with the $M L O$ gene family (see below). Plants can also modify their transporter systems to relocate sugars away from infected cells, thus impeding fungus development $[40,41]$. Orthologs of the STP13 (Sugar Transport Protein 13) subfamily seem to play a key role in this mechanism.

After the infection takes hold, the hyphae elongate and branch, forming circular colonies. Upon the anchoring of fungus to the host tissue, the only mechanism of resistance the plant still has in its disposal is the hypersensitive response (HR), which is a specific type of programmed cell death [21,42]. Despite its irreversibility, it is a major defense mechanism against powdery mildew that has been described in numerous species and largely exploited in breeding for resistance against this pathogen [8]. 


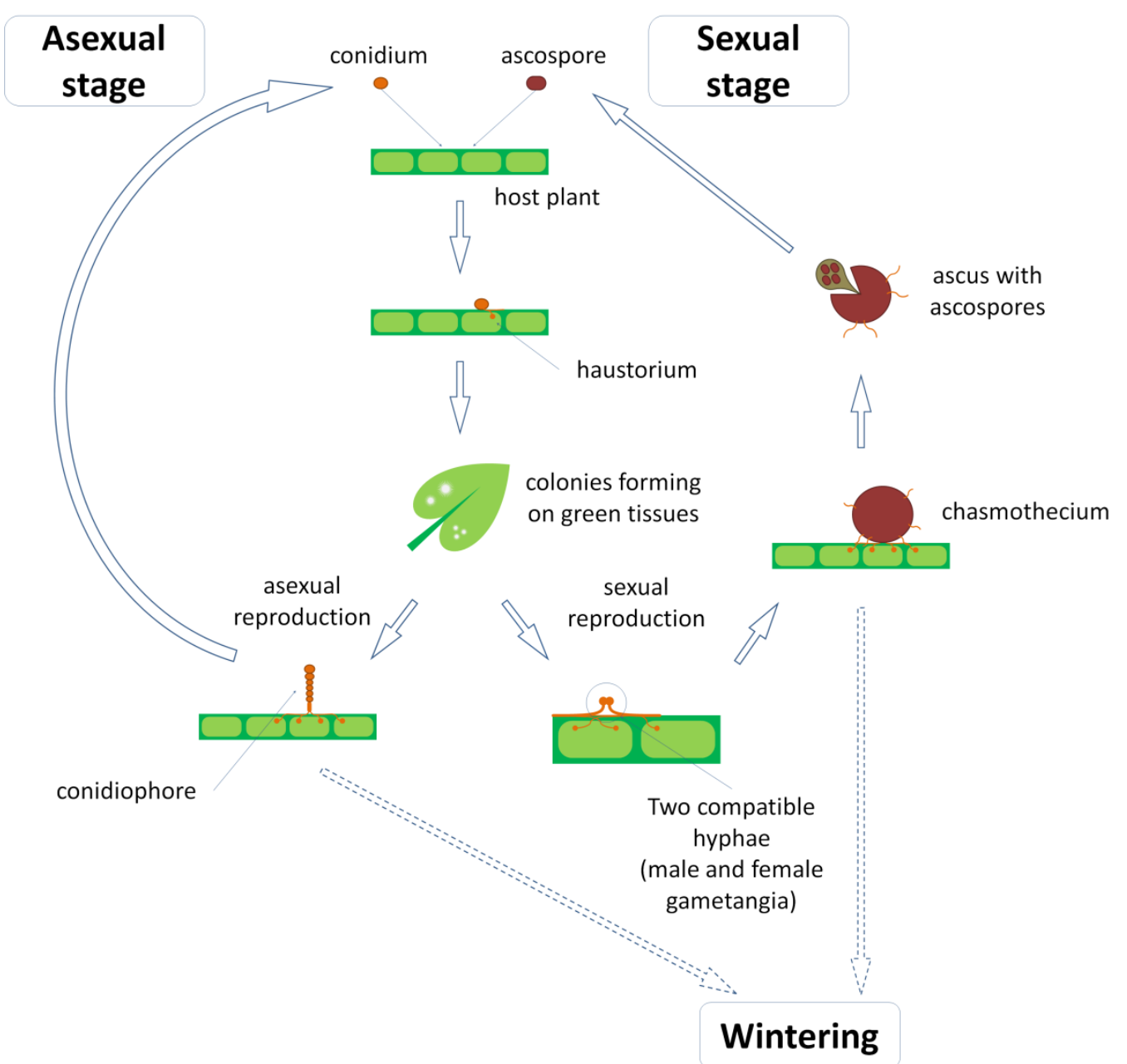

Figure 1. General scheme of powdery-mildew life cycle. Details are explained in text.

Within several days of a successful infection, the development of the reproductive structures called conidiophores begins [12]. The first cell of the conidiophore becomes the so-called foot cell which supports one or more additional cells, including the apical generative cell that produces conidia. Conidia are single monokaryotic cells with a large number of water-filled vacuoles, which probably explains their unique ability to germinate in the absence of free water $[43,44]$.

The exact mechanism of the release of conidia is unclear; the proposed mechanism involves mechanical force, wind and electrostatic charges [45-47]. The majority of the spores are released before midday, and a high relative humidity is known to impair this process $[12,46,48]$. The conidial dispersal is generally thought to occur over short distances, about $2 \mathrm{~m}$ from the host plant [49], though some findings, namely in the Erysiphe genus, suggest they can travel up to $700 \mathrm{~km}$ [50]. It appears that the amount of conidia produced and the density of the host population are directly related to the range of dispersal.

Sexual reproduction in powdery mildews occurs more rarely and is initiated by the production of male and female gametangia (antheridia and ascogonia, respectively) [51] After the cytoplasmic merge (plasmogamy), the nucleus from the antheridium migrates into the ascogonium, resulting in the dikaryon [12,51]. Then monokaryotic cells at the base of the ascogonium begin to produce hyphae that form the outer layer of the ascocarp, which in powdery mildews is usually called the chasmothecium. The dykariotic ascogonium starts to divide, producing multiple dykariotic cells which then develop into asci that contain between two and eight ascospores, depending on the species [52]. Mature chasmothecia can be either anchored in place or separable from the parental mycelium [31,51,52]. In the second case, they have protrusions that could be helpful in dislodging them from the 
substrate and keeping them airborne as they are carried by the wind [12]. Sometimes ascospores can germinate within asci in the chasmothecium [53], but usually chasmothecium split open, discharging ascospores. The split is caused by the increased turgor pressure of the absorbed water, so the discharge occurs in high moisture, usually following rain $[31,54]$.

Because Erysiphales are obligate parasites, they must be able to survive during periods when susceptible hosts are unavailable for infection. Chasmothecia are the primary dormant form of powdery mildew, which are suitable to withstand both cold winter and hot, dry summer [54]. Parts of mycelia with haustoria and even conidia can also persist within the dormant buds of host plants, causing a rapid infection shortly after sprouting [55].

\subsection{Powdery Mildew in Legumes}

The powdery-mildew disease in legumes provides an example of host-parasite specificity, although the exact taxonomic status of legume powdery mildews is still not well understood, as the taxonomy itself undergoes constant and rapid changes [56]. The only powdery-mildew species causing the disease in the majority of pulse crops, including peas (Pisum sativum) and alfalfa (Medicago sativa L.), was thought to be Erysiphe pisi DC, which consists of three formae speciales (host-specific groups): E. p.f.sp. pisi, E. p.f.sp. medicaginis and E. p.f.sp. vicia-sativa [57]. However, two more Erysiphe species have been reported to infect peas and lentils (Lens culinaris Medik.): E. trifolii Grev. and E. baumleri (Magnus) U. Braun \& S. Takam [58-60]. The main agent of powdery mildew in soybeans (Glycine max (L.) Merr.) belongs to E. diffusa (Cooke \& Peck) U. Braun \& S. Takam (formerly Microsphaera diffusa), though Erysiphe glycines F.L. Tai has also been reported to infect this plant $[8,61]$. Cowpeas (Vigna unguiculata (L.) Walp.) and chickpeas (Cicer arietinum L.) are affected by Podosphaera phaseoli (Z.Y. Zhao) U. Braun \& S. Takam and Leveillula taurica (Lév.) G. Arnaud, respectively [8]. Black gram (Vigna mungo (L.) Hepper) can be infected by E. polygoni DC [62].

The taxonomic ambiguity and difficulties with identification of powdery mildews are gradually becoming prominent obstacles to researchers and breeders, since even the strictest natural resistance is not universal and previously effective alleles could become useless against newly arisen pathogens. Meanwhile, powdery-mildew contamination can be fatal for legume crops. According to data, powdery-mildew outbreaks caused by E. diffusa can reduce the yield of soybeans by $50-60 \%$ in the cases of susceptible cultivars, with average losses being about 30\% [63,64]. For the other legumes, the situation is not encouraging either: E. polygoni leads to a yield loss of black gram by $40 \%$ [65]; E. pisi can annihilate up to half $(50 \%)$ of a pea crop $[13,66]$. Thus, strict pathogen control and breeding for new legume cultivars with broad resistance to powdery mildew are of paramount importance nowadays.

\section{The Art of War}

\subsection{Chemical Control of the Powdery Mildew}

Powdery mildew is one of the most prominent pathogens of legumes that is able to cause severe damage to the yield, thus a broad spectrum of disease-control methods is used to prevent its spreading. The most basic method is the appliance of various fungicides, mainly sulfur-containing compounds [13,67]. Different agents can affect fungus at different stages of the life cycle and in various physiological conditions, by disrupting cell division (benomyl, carbendazim), cell-wall synthesis and membrane functions (triadimenol, fenarimol, tridemorph) or spore germination (chlorothalonil) [68-75]. However, there are a number of serious drawbacks in this strategy. The cost and logistics of repeatable preventive appliances prevent many farm holds from using it, especially in the developing countries where the mildew problem is looming large. The application of fungicides only after the disease has already been observed is more realistic and cost-effective, but requires constant monitoring and precise timing, as the fungicide must be applied when the number of plants infected is low and the infection level of each plant is minimal [13]. Moreover, some of the most widely used fungicides have been prohibited in the EU since 2009 due to the 
environmental risks and/or human health issues they can cause (Regulation (EC) No. $1107 / 2009$ of the European Parliament and of the Council). Despite all this, for lack of a better solution, fungicides continue to be widely studied and applied.

The negative public attitude towards the pesticides, environmental concerns, the expensiveness of commercial formulations, and the appearance of resistant powderymildew strains have led to the search for alternative methods to control the fungus. Nonfungicidal products used in powdery-mildew management include salts, oils, plant extracts, sclerotial exudates, compost tea extracts and even cow urine [76-80]. Some progress has been achieved using bergenin (isolated from Flueggea microcarpa Blume) [81], ajoene (constituent of garlic) [82] and extract from ginger [80,83]. Some of these agents are aimed at inducing or increasing the level of systemic resistance, thus "preparing" plants for subsequent pathogen attack. Plant hormones such as salicylic acid and pathogen-associated molecules such as chitosan are often used to that end with promising results [84,85]. This approach may potentially provide commercially useful broad-spectrum plant protection that is stable, readily available, long lasting and environmentally friendly.

\subsection{Biological Control of the Powdery Mildew}

As appealing as they may seem, the biological methods of powdery-mildew management remain a matter of the not-so-near future [13]. To date, there have been some encouraging results in the practical biocontrol of a number of powdery-mildew diseases, but they are mostly still limited to the laboratories and await large-scale agricultural trials. Attempts have been made to control powdery mildews with mycolytic bacteria, mycophagous arthropods, fungi, yeasts and other possible biological agents [86,87]. The most promising biological-control trials involving a number of natural antagonists of powdery mildews have resulted in the development of several biofungicide products. One well-known antagonist of species of the order Erysiphales and some other plant pathogens such as Mucorales and Perisporales is Ampelomyces quisqualis Ces. [87]. Considerable success was also achieved with Trichoderma harzianum Rifai, which resulted in a decreased number of colonies on the leaf surface $[87,88]$. Speaking of legumes, the importance of mutualistic plant-microbial interactions in terms of pathogen management should also not be neglected. A good example is the soybean interaction with Bradyrhizobium japonicum (Kirchner, 1896) Jordan, 1982. Nod factors (symbiotic signal molecules) of B. japonicum were reported to reduce the number of infection events and the size of powdery-mildew colonies [89]. A later study performed on peas (Pisum sativum) and barrel medics (Medicago truncatula Gaertn.) suggests that root symbiosis with rhizobia systemically primes plants for the salicylic-acid accumulation and defense-gene expression triggered by powdery mildew [90].

While the plant-rhizobial association is a specialized type of symbiosis that is inherent in a limited range of species, mycorrhiza is formed by approximately $90 \%$ of terrestrial plants [91]. Although mycorrhizal fungi are the most ancient mutualists of plants, the pattern of their behavior during host colonization strongly resembles that of the powdery mildews, which allows them to be considered as natural antagonists and potential biocontrol agents [92]. Indeed, it has been shown on multiple occasions that mycorrhiza positively affects the plant resistance to powdery mildew, decreasing the severity of infection [93-95]. However, given the wide variety of fungi species capable of forming mycorrhiza and the low specificity of this symbiosis, the data on the effectiveness of such a method of protection differ significantly depending on the specific host-symbiont pair. Thus, it was shown that wheat plants mycorrhized with Funneliformis mosseae (T.H. Nicolson \& Gerd.) C. Walker \& A. Schüssler exhibit resistance to the pathogen Blumeria graminis (DC.) Speer f. sp. tritici, reducing colonization by $78 \%$, while association with Rhizophagus irregularis (Błaszk, Wubet, Renker \& Buscot) C. Walker \& A. Schüßler reduces colonization by only 34\% [96]. At the same time, cucumber (Cucumis sativus L.) plants colonized by the arbuscular mycorrhiza fungus Glomus intraradices N.C. Schenck \& G.S. Sm. did not demonstrate an increased resistance to powdery mildew [97], and standing milkvetch (Astragalus adsurgens Torr.) became even more susceptible to the disease when mycorrhized [98]. Taking all of the 
above into account, mycorrhiza undoubtedly benefits the plant, but it cannot be considered as the main and universal method of protection against powdery mildew.

Another microorganism suitable for powdery-mildew control is Bacillus subtilis, as well as B. amyloliquefaciens, B. pumilus, and several others [99-105]. Pseudomonas fluorescens and P. aeruginosa were also proven to suppress powdery mildew when applied on seeds as spray or suspension $[105,106]$. Recently, reports were published about the biocontrol potential of cyanobacteria (Spirulina platensis (Gomont) Geitler) in a mixture with P. fluorescens as well as on their own [107]. Non-pathogenic epiphytic microorganisms that normally colonize the plant can also play an important role in host defense against powdery mildew, either by competitive suppression, parasitism, antibiotic production or induced resistance $[108,109]$. Pseudozyma flocculosa (Traquair, Shaw \& Jarvis) Boekhout \& Traquair, the yeast-like basidiomycetous fungus, is unique in that it actually exploits the powdery-mildew pathogen (B. graminis) as a conduit to extract nutrients from the plant itself, causing the rapid disruption of mildew colonies [110]; nowadays, this fungus is considered one of the most promising biocontrol agents [109]. Nonetheless, most biological methods still need to be a part of an integrated treatment or a preventative measure, since the efficiency of bioagents can be significantly influenced by environmental conditions.

However, the most promising is the genetic approach based on the identification of naturally occurring/mutagen-induced variances with resistance to powdery mildew and their inclusion into breeding programs. Once established, genetic resistance is the cheapest and most efficient strategy of disease management, as it is more economically and environmentally friendly than, for example, chemical control. In the second half of the 20th century, the Eastern world turned to the ideas of humanism and began looking for solutions to the global problems of humanity, in particular, the problem of starvation, which was especially acute in developing countries. Legumes are excellent sources of nutrition, which, together with them being undemanding in terms of soil conditions due to nitrogen fixation, makes them an essential component of agriculture in these countries [111,112]. Unfortunately, the range of crops available in these countries is usually limited to the so-called "landraces" with low productivity, and the introduction of quality cultivars is complicated by high pathogenic activity, especially with regard to fungi [113,114]. To improve the quality of cultivars, about 50 years ago a worldwide program was started with the aim of the improvement of crops in terms of yield stability and performance, with much attention focused on disease resistance (World Food Conference, 1974; World Conference on Agrarian Reform and Rural Development, 1979). Among legumes, special attention was paid to mung beans, soybeans, cowpeas, chickpeas and garden peas, for which resistance to powdery mildew has become one of the fundamental selective traits, since this disease is especially dangerous in the regions of their active cultivation. Since then, researchers have made remarkable strides in finding disease-resistant legume varieties, identifying the genes responsible for this trait, and using this knowledge in breeding programs. However, there are certain difficulties and nuances that will be discussed below.

\section{Close the Gate}

When it comes to the genetic mechanisms of resistance to pathogens, the key role belongs to the so-called systemic acquired resistance (SAR), which is associated with the expression of resistance genes (R-genes) and the triggering of the hypersensitivity reaction (HR) $[9,115,116]$. This mechanism allows plants to cope with the daily presence of nonspecific and opportunistic pathogens. On the other hand, specific pathogens, for which a given plant is the primary host, have evolutionarily acquired ways to bypass the SAR by interacting with special target proteins, which serve as a kind of "gateway" into the host organism [116,117]. The genes encoding such proteins are called S-genes (susceptibility genes). The loss-of-function mutations in S-genes often lead to the broadspectrum resistance to a particular kind of pathogen, as they effectively "close the gates" to the plant for this pathogen $[115,116]$. 
The history of studying the genetic mechanisms of plant resistance to powdery mildew began with barley (Hordeum vulgare L.), which was found to have the Mla gene locus (for "Mildew locus A") that provides resistance to Blumeria graminis f. sp. hordei based on the "gene-for-gene" principle [118,119]. The Mla genes (Mla-1 to Mla-32) are typical R-genes that encode the nucleotide-binding-site LRR proteins, presumably allowing recognition of race-specific fungal proteins, which leads to the induction of HR and the development of SAR [120,121]. Nonetheless, due to their nature, Mla genes are only able to provide race-specific resistance to powdery mildew. However, durable broad-spectrum resistance to B. graminis f. sp. hordei in barley also exists, caused by recessive, loss-of-function mutations in a single gene called Mlo (for "Mildew locus O") [122].

Mlo encodes an integral-membrane protein with seven transmembrane helices and is a classic S-gene that allows fungi to penetrate plant cells [123,124]. Mutations that disrupt its structure prevent the normal fungus penetration through the epidermal cell wall without triggering a cell-death response. Further studies revealed that $M L O$ genes (note that there are differences in nomenclature depending on the species: in barley, they are traditionally written as $M l o$, while $M L O$ is used as a more general spelling) occur as small to medium-sized families in the genomes of higher plant species, monocots and dicots alike [124,125]. This discovery led to the identification of natural or induced loss-of-function mlo alleles associated with powdery-mildew resistance in several agriculturally important plants, including the garden pea, which is the representative of the legumes [14,15]. It appeared that MLO proteins were part of a sizable family. The 15 Arabidopsis MLO proteins were originally grouped into four major clades (I-IV) [126]. Subsequently, a more detailed analysis including 17 MLO members of the grapevine (Vitis vinifera L.) and several of those from barley, bread wheat (Triticum aestivum L.), rice (Oryza sativa L.) and corn (Zea mays L.) distinguished six distinct clades [127]. Additionally, several studies have proposed the existence of clade VII, which would be represented by MLO11 from the cucumber (Cucumis sativus L.) [128] and MLO2 from the tomato (Solanum lycopersicum L.) [129]. The recent study of [130] expanded clade VII to 21 members from dicots, as well as postulated the existence of clade VIII with six monocot-specific members. The work is still in progress, and the data are constantly being updated. To date, all MLO proteins from dicot species that are known to be associated with powdery-mildew susceptibility are sorted into clade $\mathrm{V}$, while the monocot species are grouped into clade IV along with several recently discovered representatives from the dicots, namely legumes (Medicago truncatula) [124,127,131].

The exploitation of such an appealing trait as mlo-based resistance in a broad spectrum of crops is not without its limitations. It appears that, in the absence of pathogens, barley mlo mutants tend to spontaneously form callose-containing cell-wall papillae, predominantly in the short-cell type of the leaf epidermis [132]. Additionally, leaf mesophyll cells in mlo mutants undergo spontaneous cell death [133], which has been recognized as an indication of accelerated leaf senescence. Similar mlo-associated pleiotropic effects have also been observed in Arabidopsis plants [38,134].

Being the first legume species with well-documented mlo-based resistance (caused by the loss of function in gene MLO1, also known as Er1 [14,15]), the garden pea (Pisum sativum) possesses yet another notable feature: known pea mlo mutants are spared the negative pleiotropic effects of their mutations [14]. It is thus no wonder that from the moment of its discovery to this day, MLO1 remains a very actively studied gene. There are eleven previously reported Psmlo1 (er1) alleles, either of natural origin or obtained by mutagenesis, that confer resistance to the main legume powdery mildew Erysiphe pisi (see Table 1). Several function markers covering the majority of these alleles have been designed for breeding assistance [15,135-140]. The er1-7 and er1-8 alleles were independently found in the analysis of powdery-mildew-resistant accessions from the pea-germplasm collection of the John Innes Centre (Norwich, UK) performed in the All-Russia Research Institute for Agricultural Microbiology (Saint-Petersburg, Russia). The sources of these alleles have germplasm collection numbers JI1128 and JI1171 (er1-7) and JI0092, JI0101 and JI0105 (er1-8). In the same analysis, a new resistant allele er1-12 with an A insertion at position 1735 of 
the PSMLO1 cDNA was also identified. The line carrying this allele is named JI2019 in the John Innes Centre germplasm collection and originates from India [141]. The details of this work are described in Appendix A.

Table 1. List of known Psmlo1 (er1) alleles conferring resistance to powdery mildew.

\begin{tabular}{|c|c|c|c|}
\hline Psmlo1 Allele & Mutation & Cultivar/Landrace & Place of Origin \\
\hline \multirow{3}{*}{$\begin{array}{c}\text { er1-1 } \\
\text { (er1mut1) }\end{array}$} & \multirow{3}{*}{$\mathrm{C} \rightarrow \mathrm{G}$ at position 680 of cDNA } & Mexique 4/JI1559 [14] & Mexico \\
\hline & & S [142] & $\begin{array}{c}\text { Portugal (mutant obtained on } \\
\text { the Solara cultivar) }\end{array}$ \\
\hline & & Tara [143] & $\begin{array}{c}\text { Canada (obtained on material } \\
\text { from Argentine) }\end{array}$ \\
\hline \multirow{7}{*}{ er1-2 } & \multirow{7}{*}{$\begin{array}{l}\text { Large transposon insertion of } \\
\text { unknown size in 14th exon } \\
\text { (position } 1262 \text { of cDNA) leading to } \\
\text { formation of various aberrant } \\
\text { MLO1 transcripts }\end{array}$} & Stratagem/JI2302 [14] & Mexico \\
\hline & & Franklin/PI 628275; & USA (on an unknown \\
\hline & & Dorian; & $\begin{array}{l}\text { USA (on an unknown } \\
\text { material) }\end{array}$ \\
\hline & & Nadir [15] & \\
\hline & & [137,144]: & \\
\hline & & Xucai 1 [145]; & China \\
\hline & & G0005576 [144] & \\
\hline er1-3 & G deletion at position 862 of cDNA & JI0210/Lucknow Boniya/PI 240515 [14] & India \\
\hline er $1-4$ & A deletion at position 91 of cDNA & $\begin{array}{c}\text { YI; } \\
\text { JI1951 [14] }\end{array}$ & China \\
\hline er1-5 & $\mathrm{G} \rightarrow \mathrm{A}$ at position 567 of cDNA & $\mathrm{ROI} / 02$ [15] & $\begin{array}{l}\text { Italy (mutant obtained on the } \\
\text { Sprinter cultivar) }\end{array}$ \\
\hline
\end{tabular}

Wandou G0001752, Baiwandou

G0001763, Dabaiwandou G0001764,

Fanwandou G0001767, Wandou

G0001768, Dabaiwandou G0001778,

China

er1-6 $\quad \mathrm{T} \rightarrow \mathrm{C}$ at position 1121 of cDNA

Dabaiwandou G0001780, Wandou

G0003824 [144]

\begin{tabular}{|c|c|c|c|}
\hline er1-7 & $\begin{array}{l}\text { TCATGTTATT deletion at position } \\
111-120 \text { of cDNA }\end{array}$ & $\begin{array}{l}\text { DDR-11 [136] } \\
\text { JI1128 (see Appendix A of this article) } \\
\text { JI1171 (see Appendix A of this article) }\end{array}$ & $\begin{array}{l}\text { India } \\
\text { India } \\
\text { India }\end{array}$ \\
\hline er1-8 & $\begin{array}{l}\text { GTG deletion at position 1339-1341 } \\
\text { of cDNA }\end{array}$ & $\begin{array}{c}\text { G0004839 [135] } \\
\text { JI0092/PI 134271 (see Appendix A of } \\
\text { this article) } \\
\text { JI0101/PI 220175 (see Appendix A of } \\
\text { this article) } \\
\text { JI0105/PI 222070 (see Appendix A of } \\
\text { this article) }\end{array}$ & $\begin{array}{l}\text { Afghanistan } \\
\text { Afghanistan } \\
\text { Afghanistan } \\
\text { Afghanistan }\end{array}$ \\
\hline er1-9 & T deletion at position 928 of cDNA & G0004400 [135] & Australia \\
\hline er1-10 (er1mut2) & $\mathrm{G} \rightarrow \mathrm{A}$ at position 939 of cDNA & F [142] & $\begin{array}{c}\text { Portugal (mutant obtained on } \\
\text { the Frilene cultivar) }\end{array}$ \\
\hline er1-11 & $\begin{array}{l}\text { GT insertion at position 2974-2975 } \\
\text { of genomic DNA (intron 11) }\end{array}$ & Yarrum, ps1771 [138] & Australia \\
\hline er1-12 & $\begin{array}{l}\text { A insertion at position } 1735 \text { of } \\
\text { cDNA }\end{array}$ & JI2019 (see Appendix A of this article) & India \\
\hline
\end{tabular}

\section{Gathering Forces}

The successes achieved with peas, coupled with advances in molecular biology and the development of "omics" technologies, stimulate the search for mlo-based immunity in other legumes, from well-established models such as the barrel medic to valuable crops such as soybeans to so-called "orphan" crops such as mung beans or chickpeas [21,131,146-149]. A promising approach is a whole-genome screening for all the sequences homologous to $M L O$ 
with subsequent targeted knockout using CRISPR-Cas, or a search for induced mutants with TILLING [150]. For some species, there is previously obtained data on resistance to powdery mildew available, including the most prominent model legume, the barrel medic (Medicago truncatula) [21]. With its diploid and relatively small ( $500 \mathrm{Mb})$ genome, self-pollination and close relations with main-crop legumes, $M$. truncatula is an extremely convenient object of study. The fact that $M$. truncatula can serve as a resource of resistance genes to powdery mildew is evidenced by various phenotypes, from completely resistant to highly susceptible $[151,152]$. This wide range of plant reactions to powdery mildew suggests the existence of different resistance mechanisms which, given the development level of $M$. truncatula genetics, could be thoroughly investigated. Unfortunately, the amount of resistant $M$. truncatula cultivars discovered so far is not large; for instance, of 277 samples, only 10 showed complete or moderate sustainability [151].

In 2008, three major QTLs of $M$. truncatula responsible for different levels of powderymildew resistance were found, namely Epp 1 (located on chromosome 4), Epa1 and Epa2 (both located on chromosome 5) [153]. It is worth mentioning that the phenotype of different genetic mechanisms of resistance was the same: E. pisi was not able to penetrate the cell wall of the plant (which suggests the possible involvement of $M L O$ homologs). In 2016, a wide search for $M L O$-like sequences was performed among the seven legume species with available genomes, namely $M$. truncatula, Cicer arietinum, Lupinus angustifolius L., Cajanus cajan (L.) Huth, Phaseolus vulgaris L., Vigna radiate (L.) R. Wilczek and Arachis spp. [131]. The transcriptomic data for Pisum satioum were also included. All studied genomes contained between 14 and 23 sequences with homology to MLOs from Arabidopsis thaliana used as a BLAST query, including some short truncated sequences. Most of the latter were designated as inactive pseudogenes due to their proximity to the retrotransposon-like sequences. However, some of these short genes probably belong to a clade VII of $M L O$, as similar sequences were detected in the cucumber, tomato, apple and strawberry. The exact properties and functions of these genes remain to be studied.

In $M$. truncatula, $16 M L O$ genes were found, including two dubious truncated sequences. The 14 "true" MLOs were distributed among 6 of the $7 M L O$ clades. However, the most intriguing is the fact that besides two clade $\mathrm{V} M L O$ genes usually found in temperate legumes, $M$. truncatula also possessed one clade IV MLO gene that was thought to be restricted to monocots. The function of this additional gene in eudicots is currently unknown.

Not only the genetic aspects can be studied in the E. pisi-M. truncatula pathosystem; the role of epigenetics is also of high interest. In 2013, Yang et al. [154] found the MtREP1 gene on chromosome 5. Three candidate genes for its role were identified, but only one remained-Medtr $5 g 072340$ - because plants carrying this gene showed resistant phenotypes. Further studies revealed that the key difference between dominant and recessive alleles was not in the sequence itself, but in the epigenetic modification, specifically in different levels of methylation.

The soybean (Glycine max) is one of the world's most important protein sources and the most cultivated legume. At least three species from the Erysiphe genus are reported to create a pathosystem with the soybean: E. pisi (pathogenic for a wide range of legumes), $E$. diffusa and E. glycines [61]. It is known that soybean resistance to E. diffusa is regulated by three alleles of the Rmd locus, located on chromosome 16 (linkage group J) $[155,156]$. Rmd-c is required for complete resistance to powdery mildew throughout the whole life cycle of a plant. Rmd causes resistance only at late stages of development, while rmd is found in susceptible plant samples [157]. In addition, another gene of resistance was shown, namely Rmd_PI243540, which also provides resistance throughout all stages of growth. In this case, the trait is controlled by a single dominant gene $[63,158]$.

The soybean was actually the very first legume to undergo a wide-scale search for $M L O$ homologues [148]. Subsequently, several $M L O$ genes were found located on the same chromosome where Rmd was previously mapped. Overall, 31 full-length $M L O$ sequences were identified, making the soybean one of the most, if not the richest legume in terms of $M L O$ genes. These genes were present on 15 of 20 chromosomes, mostly located on 
chromosome 12 (5 MLO genes). G. max is known as a paleopolyploid that underwent a couple of duplication events millions of years ago $[159,160]$, which could explain the high number of $M L O$ in its genome.

Later, two more representatives of the Milletoid clade, the pigeon pea (Cajanus cajan) and common bean (Phaseolus vulgaris) [146,161], have been screened for MLO-like sequences. A total of 18 (C. cajan) and 20 (P. vulgaris) MLO family members have been identified, and for each species, two genes have been predicted to participate in powdery-mildew resistance. So far, similar work has been performed on lentils (Lens culinaris) [162], mung beans (Vigna radiata) [163], cultivated peanuts (Arachis hypogaea L.) [164], as well as many non-legume species. In each case, candidates have been identified for the role of powderymildew-resistance genes.

\section{Para Bellum: Future Perspectives and Challenges}

Powdery-mildew control remains an important problem for modern agriculture, despite the incremental growth in the knowledge of the pathogen itself and the molecular mechanisms of plants' defense against it. In accordance with new findings, the systematics of pathogenic fungi is undergoing significant changes, but only a fraction of the described species have been reassessed using molecular-genetics approaches and some large areas still rely on the obsolete taxonomy [12]. Moreover, some mildew species seem to rapidly increase their geographical distribution, presumably due to climate changes, bringing disturbances and changes into long-established host-pathogen systems [12,165,166]. In legumes, this is reflected by the fact that new pathogens are being found that were unknown to cause disease in a given species. In particular, Erysiphe baeumleri and Erysiphe trifolii have recently been reported in peas and lentils that were previously thought to be damaged only by E. pisi [58,59]. As a result, we are becoming increasingly aware that even the most reliable methods of dealing with mildew can misfire when the pathogen's disposition changes unpredictably. Under these circumstances, a promising approach seems to be not to endow cultivars with resistance to pathogens by introducing R-genes, which eventually could be overcome by pathogens that manage to win the "Red Queen race" (see the Red Queen hypothesis, according to which, if a species is to survive, it must evolve continuously and rapidly [167]), but to modify the systems used by pathogens to colonize the host (S-genes) so they can no longer serve this purpose. This will result in broad and durable resistance to pathogens, as seen in the case of powdery mildew $[115,116]$.

Among all of the agriculturally important legumes, the pea can benefit the most from S-gene-based broad-spectrum resistance to powdery mildew, since it demonstrates no negative side effects of loss-of-function mutations in the MLO1 gene, also known as Er1. This is probably the reason for the presence of such a large number of naturally occurring resistant alleles of MLO1 in pea germplasm; at the moment, 11 of them have been described, including one found by the authors of this review (Table 1). Moreover, it has two more described genes conferring powdery-mildew resistance, recessive er2 and dominant Er3, which act at different stages of the fungus penetration $[35,168]$; additional genes are being thoroughly researched using the genomic assembly that was recently made available and modern genome-wide methods of analysis [169,170]. The data obtained on other legume species, such as Medicago truncatula or Glycine max, have also expanded the knowledge about the diversity of the molecular mechanisms of resistance of legumes to powdery mildew. Since legumes are important components of modern agronomy due to their ability to fix atmospheric nitrogen in symbiosis with nodule bacteria, this knowledge will be of high demand for the creation of new varieties of legumes that are resistant to powdery mildew, for instance, by using genome-editing technologies for modification of the host S-genes, similarly to the naturally-occurring mlo1-based system in the pea.

Author Contributions: Conceptualization, V.A.Z. and A.S.S.; methodology, V.A.Z.; formal analysis, A.S.S.; investigation, V.A.Z. and A.S.S.; resources, V.A.Z.; writing-original draft preparation, A.S.S.; writing-review and editing, V.A.Z. and A.S.S.; project administration, V.A.Z.; funding acquisition, V.A.Z. All authors have read and agreed to the published version of the manuscript. 
Funding: The article was made with support of the Ministry of Science and Higher Education of the Russian Federation in accordance with agreement No. 075-15-2020-920 date 16 November 2020 on providing a grant in the form of subsidies from the Federal budget of Russian Federation. The grant was provided for state support for the creation and development of a World-class Scientific Center "Agrotechnologies for the Future".

Acknowledgments: We would like to thank Mike J. Ambrose for sharing seeds of pea genotypes resistant to powdery mildew, Alexey Yu. Borisov for inspiring discussions and Ekaterina Vasileva for invaluable help during preparation of the manuscript.

Conflicts of Interest: The authors declare no conflict of interest. The funders had no role in the design of the study; in the collection, analyses, or interpretation of data; in the writing of the manuscript, or in the decision to publish the results.

\section{Appendix A}

Samples from the John Innes Pisum germplasm collection were selected based on the results of field screening for powdery-mildew resistance [141]. The selected samples were first subjected to the allelism test with several previously described er 1 pea lines (see Figure A1). For each crossing, at least five hybrid plants were tested. Hybrids were inoculated with powdery mildew by brushing seedlings with an infected pea plant. The phenotype was evaluated visually two weeks after inoculation by the presence/absence of mildew spots on leaves. All hybrids proved to be resistant to powdery mildew, thus the determinant of their resistance is allelic to $\operatorname{Er1}(M L O 1)$.

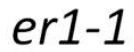

er1-2

er1-3

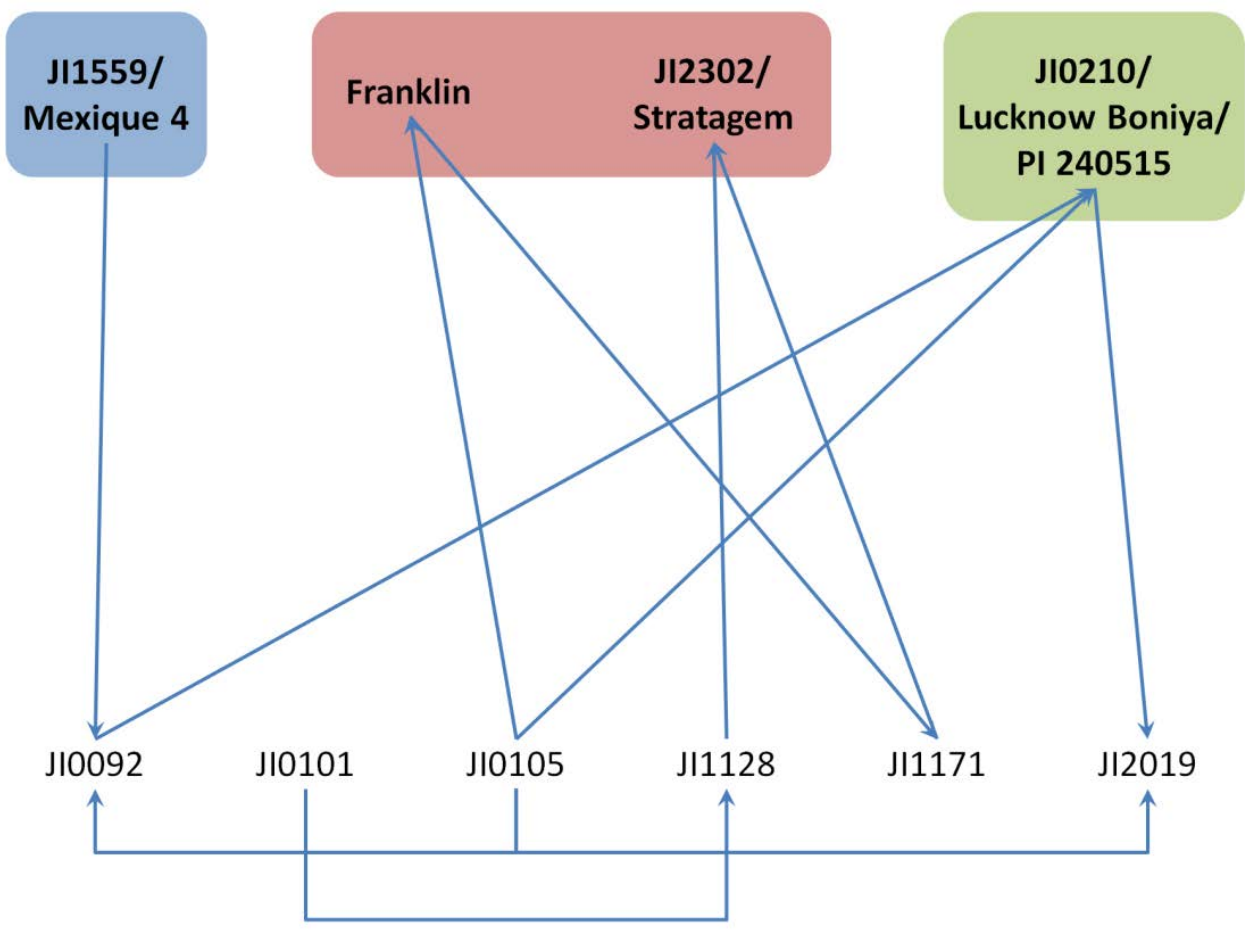

Figure A1. Scheme of the allelism test performed with the pea genotypes from the John Innes Pisum germplasm collection with unknown genetic determinants of resistance to powdery mildew (bottom row) and genotypes with previously described resistant $M L O 1$ alleles (top row). Arrows indicate directions of crosses.

For the molecular-genetic analysis, plant DNA was extracted from young leaves (top or second-from-top node) according to the previously described CTAB protocol [171,172]. RNA was extracted from similar material that was pre-frozen in liquid nitrogen and ground with a pestle and mortar. The isolation procedure was performed using the 
NucleoSpin miRNA kit (Macherey-Nagel, Düren, Germany) according to the protocol recommended by the manufacturer. The isolated RNA was additionally treated with DNase (RQ1 DNAse, Promega, Madison, WI, USA) to remove DNA residues from the samples. The concentration of the obtained RNA was determined on a Qubit 3 fluorometer (Thermo Fisher Scientific, Waltham, MA, USA). The first strand of cDNA was synthesized on a total-RNA template using the Mint cDNA kit (Evrogen, Moscow, Russia) according to the manufacturer's protocol.

The PCRs were performed in $0.5 \mathrm{~mL}$ Eppendorf-type microcentrifuge tubes on an iCycler (Bio-Rad, Hercules, CA, USA) or Dyad (Bio-Rad, USA) thermocycler using the ScreenMix-HS kit (Evrogen, Moscow, Russia). The cycling conditions were as follows: $95^{\circ} \mathrm{C}(5 \mathrm{~min}), 35 \times\left[95^{\circ} \mathrm{C}(30 \mathrm{~s}), \mathrm{Tm}\right.$ (varying depending on primers) $\left.(30 \mathrm{~s}), 72{ }^{\circ} \mathrm{C}(1 \mathrm{~min})\right]$, $72{ }^{\circ} \mathrm{C}(5 \mathrm{~min})$. The PCR fragments were sequenced using the ABI Prism3500xL system (Applied Biosystems, Palo Alto, CA, USA) at the "Genomic Technologies, Proteomics, and Cell Biology" Core Center of the ARRIAM (St. Petersburg, Russia). Primers used in this work are listed in Table A1.

Table A1. Primers used in PCR analysis.

\begin{tabular}{ccc}
\hline Name & Sequence, $\mathbf{5}^{\prime}-\mathbf{3}^{\prime}$ & Melting $^{\circ}$ \\
\hline Er1_fw0 & GAA AGA AAA AAT GGC TGA AGA GG & 59.2 \\
Er1_fw1 & GAT AAG GGT CAA GTT GCA TTA G & 58.4 \\
Er1_fw3 & TTT CCA AAA GTA TAT AAG TAG ATC & 55.0 \\
Er1_rv2 & TAA GAA GGA AAA GCA CTG TGA AG & 59.2 \\
PsMLO7Fw & ATG CCA TGT CTC CTG TTC ACC & 61.2 \\
PsMLO5Rv & CTT TAT CTG CAA GAA TGT ACC & 55.4 \\
\hline
\end{tabular}

The same primers were used for both cDNA and gDNA amplification, as they are positioned within exons.

Of six lines tested, five proved to possess already described er 1 alleles, namely er1-7 (JI1128 and JI1171) and er1-8 (JI0092, JI0101 and JI0105). However, line JI2019 appeared to have previously unknown er 1 allele with an additional $\mathrm{A}$ in the beginning of the last exon which shifts the reading frame (see Figure A2). Thus, we propose the name er1-12 for this newly described PSMLO1 allelic variant.

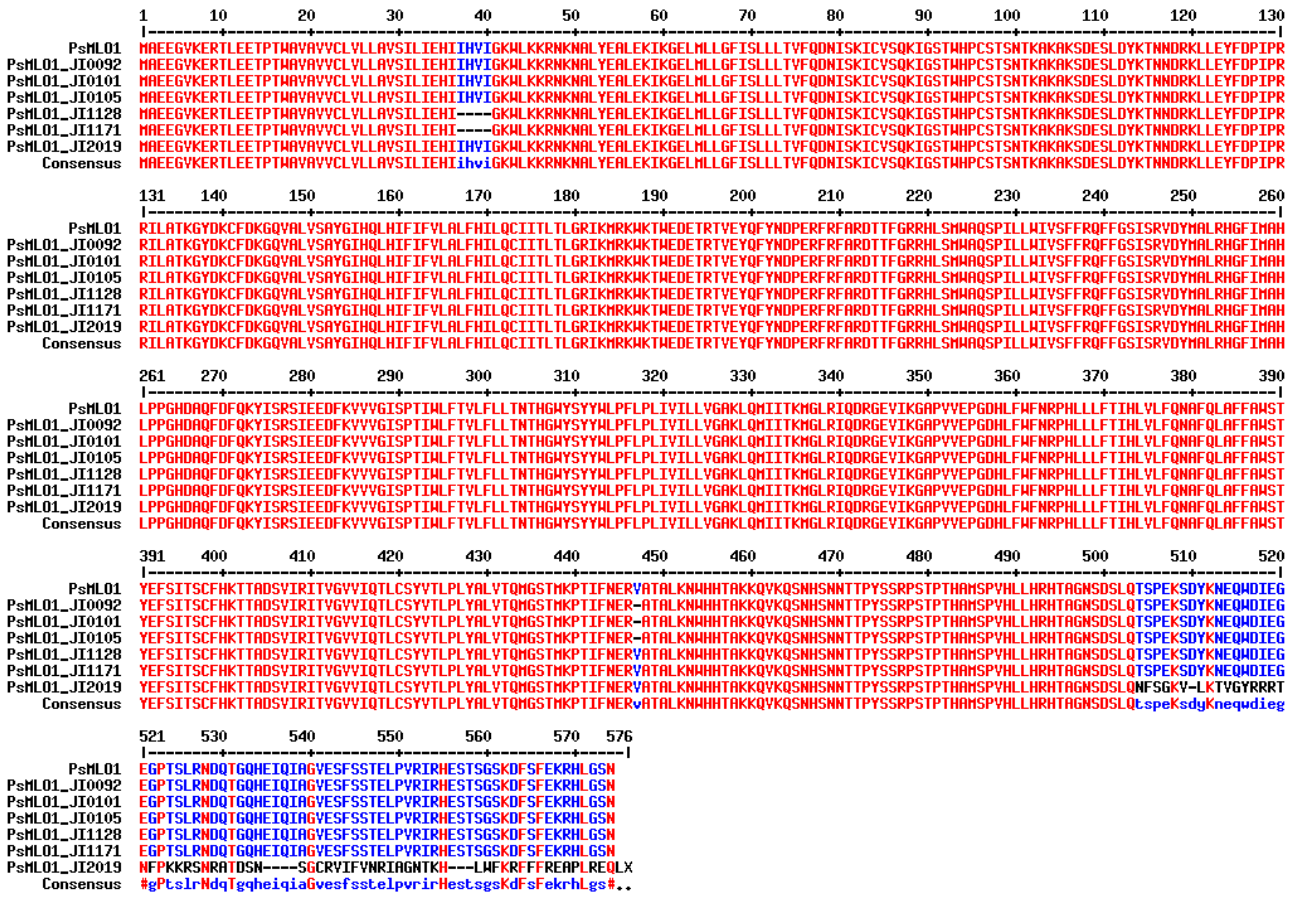

Figure A2. Comparison of translated protein sequences of MLO1 (Er1) of studied pea genotypes (obtained via Multalin web service [173], http:/ / multalin.toulouse.inra.fr/multalin/multalin.html). 


\section{References}

1. Tripathi, K.; Gore, P.G.; Singh, M.; Pamarthi, R.K.; Mehra, R.; Gayacharan, C. Legume Genetic Resources: Status and Opportunities for Sustainability. In Legume Crops-Prospects, Production and Uses; IntechOpen: London, UK, 2020. [CrossRef]

2. Smýkal, P.; Coyne, C.J.; Ambrose, M.J.; Maxted, N.; Schaefer, H.; Blair, M.W.; Berger, J.; Greene, S.L.; Nelson, M.N.; Besharat, N.; et al. Legume Crops Phylogeny and Genetic Diversity for Science and Breeding. CRC. Crit. Rev. Plant Sci. 2015, 34, 43-104. [CrossRef]

3. Collins, M.; Lang, D.J.; Kelling, K.A. Effects of Phosphorus, Potassium, and Sulfur on Alfalfa Nitrogen-Fixation under Field Conditions 2. Agron. J. 1986, 78, 959-963. [CrossRef]

4. $\quad$ Snyder, C.S.; Bruulsema, T.W.; Jensen, T.L.; Fixen, P.E. Review of greenhouse gas emissions from crop production systems and fertilizer management effects. Agric. Ecosyst. Environ. 2009, 133, 247-266. [CrossRef]

5. Hulse, J.H. Nature, composition, and utilization of food legumes. In Expanding the Production and Use of Cool Season Food Legumes; Springer: Dordrecht, The Netherlands, 1994; pp. 77-97.

6. Upadhyaya, H.D.; Dwivedi, S.L.; Ambrose, M.; Ellis, N.; Berger, J.; Smýkal, P.; Debouck, D.; Duc, G.; Dumet, D.; Flavell, A.; et al. Legume genetic resources: Management, diversity assessment, and utilization in crop improvement. Euphytica 2011, 180, 27-47. [CrossRef]

7. Maxted, N.; Dulloo, E.; Ford-Lloyd, B.V.; Iriondo, J.M.; Jarvis, A. Gap analysis: A tool for complementary genetic conservation assessment. Divers. Distrib. 2008, 14, 1018-1030. [CrossRef]

8. Rubiales, D.; Fondevilla, S.; Chen, W.; Gentzbittel, L.; Higgins, T.J.V.; Castillejo, M.A.; Singh, K.B.; Rispail, N. Achievements and Challenges in Legume Breeding for Pest and Disease Resistance. CRC. Crit. Rev. Plant Sci. 2015, 34, 195-236. [CrossRef]

9. Martins, D.; de Sousa Araújo, S.; Rubiales, D.; Patto, M.C.V. Legume crops and biotrophic pathogen interactions: A continuous cross-talk of a multilayered array of defense mechanisms. Plants 2020, 9, 1460. [CrossRef]

10. Rubiales, D.; Fernández-Aparicio, M.; Moral, A.; Barilli, E.; Sillero, J.C.; Fondevilla, S. Disease resistance in pea (Pisum sativum L.) types for autumn sowings in mediterranean environments. Czech J. Genet. Plant Breed. 2009, 45, 135-142. [CrossRef]

11. Sillero, J.C.; Fondevilla, S.; Davidson, J.; Vaz Patto, M.C.; Warkentin, T.D.; Thomas, J.; Rubiales, D. Screening techniques and sources of resistance to rusts and mildews in grain legumes. Euphytica 2006, 147, 255-272. [CrossRef]

12. Glawe, D.A. The powdery mildews: A review of the world's most familiar (yet poorly known) plant pathogens. Annu. Rev. Phytopathol. 2008, 46, 27-51. [CrossRef]

13. Fondevilla, S.; Rubiales, D. Powdery mildew control in pea. A review. Agron. Sustain. Dev. 2012, 32, 401-409. [CrossRef]

14. Humphry, M.; Reinstädler, A.; Ivanov, S.; Bisseling, T.; Panstruga, R. Durable broad-spectrum powdery mildew resistance in pea er1 plants is conferred by natural loss-of-function mutations in PsMLO1. Mol. Plant Pathol. 2011, 12, 866-878. [CrossRef] [PubMed]

15. Pavan, S.; Schiavulli, A.; Appiano, M.; Marcotrigiano, A.R.; Cillo, F.; Visser, R.G.F.; Bai, Y.; Lotti, C.; Ricciardi, L. Pea powdery mildew er1 resistance is associated to loss-of-function mutations at a MLO homologous locus. Theor. Appl. Genet. 2011, 123, 1425-1431. [CrossRef]

16. Linde, M.; Shishkoff, N. Powdery Mildew. In Reference Module in Life Sciences; Taylor \& Francis: Abingdon, UK, 2017; pp. 1-8. [CrossRef]

17. Braun, U. The current systematics and taxonomy of the powdery mildews (Erysiphales): An overview. Mycoscience 2011, 52, 210-212. [CrossRef]

18. Brown, J.K.M. Comparative genetics of avirulence and fungicide resistance in the powdery mildew fungi. In The Powdery Mildews: A Comprehensive Treatise; Bélanger, R.R., Bushnell, W.R., Dik, A.J., Carver, T.L.W., Eds.; American Phytopathological Society (APS Press): St. Paul, MN, USA, 2002; pp. 56-65.

19. Zhang, Z.; Henderson, C.; Perfect, E.; Carver, T.L.W.; Thomas, B.J.; Skamnioti, P.; Gurr, S.J. Of genes and genomes, needles and haystacks: Blumeria graminis and functionality. Mol. Plant Pathol. 2005, 6, 561-575. [CrossRef]

20. Vogel, J.; Somerville, S. Powdery mildew of Arabidopsis: A model system for host-parasite interactions. In The Powdery Mildews: A Comprehensive Treatise; Bélanger, R.R., Bushnell, W.R., Dik, A.J., Carver, T.L.W., Eds.; American Phytopathological Society (APS Press): St. Paul, MN, USA, 2002; pp. 161-168.

21. Rispail, N.; Prats, E.; Rubiales, D. Medicago truncatula as a model to study powdery mildew resistance. In The Model Legume Medicago truncatula; de Bruijn, F.J., Ed.; Wiley-Blackwell: Hoboken, NJ, USA, 2020; pp. 390-397. [CrossRef]

22. Kunoh, H.; Itoh, O.; Kohno, M.; Ishizaki, H. Are primary germ tubes of conidia unique to Erysiphe graminis? Jpn. J. Phytopathol. 1979, 45, 675-682. [CrossRef]

23. Hacquard, S. The genomics of powdery mildew fungi: Past achievements, present status and future prospects. Adv. Bot. Res. 2014, 70, 109-142. [CrossRef]

24. Takamatsu, S. Phylogeny and evolution of the powdery mildew fungi (Erysiphales, Ascomycota) inferred from nuclear ribosomal DNA sequences. Mycoscience 2004, 45, 147-157. [CrossRef]

25. Kiss, L.; Khosla, K.; Jankovics, T.; Niinomi, S.; Braun, U.; Takamatsu, S. A morphologically ill-founded powdery mildew species, Pleochaeta indica, is recognized as a phylogenetic species based on the analysis of the nuclear ribosomal DNA sequences. Mycol. Res. 2006, 110, 1301-1308. [CrossRef]

26. Takamatsu, S.; Matsuda, S. Estimation of molecular clocks for ITS and 28S rDNA in Erysiphales. Mycoscience 2004, 45, 340-344. [CrossRef] 
27. Cook, R.T.A.; Inman, A.J.; Billings, C. Identification and classification of powdery mildew anamorphs using light and scanning electron microscopy and host range data. Mycol. Res. 1997, 101, 975-1002. [CrossRef]

28. Takamatsu, S.; Braun, U.; Limkaisang, S. Phylogenetic relationships and generic affinity of Uncinula septata inferred from nuclear rDNA sequences. Mycoscience 2005, 46, 9-16. [CrossRef]

29. To-anun, C.; Kom-un, S.; Sunawan, A.; Fangfuk, W.; Sato, Y.; Takamatsu, S. A new subgenus, Microidium, of Oidium (Erysiphaceae) on Phyllanthus spp. Mycoscience 2005, 46, 1-8. [CrossRef]

30. Glawe, D.A. First Report of Powdery Mildew of Nandina domestica Caused by Microsphaera berberidis (Erysiphe berberidis) in the Pacific Northwest. Plant Health Prog. 2003, 4, 30. [CrossRef]

31. Jarvis, W.R.; Gubler, W.D.; Grove, G.G. Epidemiology of powdery mildews in agricultural pathosystems. In The Powdery Mildews: A Comprehensive Treatise; Bélanger, R.R., Bushnell, W.R., Dik, A.J., Carver, T.L.W., Eds.; American Phytopathological Society (APS Press): St. Paul, MN, USA, 2002; pp. 169-199.

32. Green, J.R.; Carver, T.L.W.; Gurr, S.J. The formation and function of infection and feeding structures. In The Powdery Mildews: A Comprehensive Treatise; Bélanger, R.R., Bushnell, W.R., Dik, A.J., Carver, T.L.W., Eds.; American Phytopathological Society (APS Press): St. Paul, MN, USA, 2002; pp. 66-82.

33. Carver, T.L.W.; Kunoh, H.; Thomas, B.J.; Nicholson, R.L. Release and visualization of the extracellular matrix of conidia of Blumeria graminis. Mycol. Res. 1999, 103, 547-560. [CrossRef]

34. Mims, C.W.; Liljebjelke, K.A.; Richardson, E.A. Surface morphology, wall structure, and initial adhesion of conidia of the powdery mildew fungus Uncinuliella australiana. Phytopathology 1995, 85, 352-358. [CrossRef]

35. Fondevilla, S.; Carver, T.L.W.; Moreno, M.T.; Rubiales, D. Identification and characterization of sources of resistance to Erysiphe pisi Syd. in Pisum spp. Plant Breed. 2007, 126, 113-119. [CrossRef]

36. Gniwotta, F.; Vogg, G.; Gartmann, V.; Carver, T.L.W.; Riederer, M.; Jetter, R. What do microbes encounter at the plant surface? Chemical composition of pea leaf cuticular waxes. Plant Physiol. 2005, 139, 519-530. [CrossRef]

37. Niks, R.E.; Rubiales, D. Potentially durable resistance mechanisms in plants to specialised fungal pathogens. Euphytica 2002, 124, 201-216. [CrossRef]

38. Consonni, C.; Humphry, M.E.; Hartmann, H.A.; Livaja, M.; Durner, J.; Westphal, L.; Vogel, J.; Lipka, V.; Kemmerling, B.; Schulze-Lefert, P.; et al. Conserved requirement for a plant host cell protein in powdery mildew pathogenesis. Nat. Genet. 2006, 38, 716-720. [CrossRef]

39. Hückelhoven, R.; Panstruga, R. Cell biology of the plant-powdery mildew interaction. Curr. Opin. Plant Biol. 2011, 14, 738-746. [CrossRef]

40. Pommerrenig, B.; Müdsam, C.; Kischka, D.; Ekkehard Neuhaus, H. Treat and trick: Common regulation and manipulation of sugar transporters during sink establishment by the plant and the pathogen. J. Exp. Bot. 2020, 71, 3930-3940. [CrossRef] [PubMed]

41. Gupta, M.; Dubey, S.; Jain, D.; Chandran, D. The Medicago truncatula Sugar Transport Protein 13 and Its Lr67res-Like Variant Confer Powdery Mildew Resistance in Legumes via Defense Modulation. Plant Cell Physiol. 2021, 62, 650-667. [CrossRef] [PubMed]

42. Mur, L.A.J.; Kenton, P.; Lloyd, A.J.; Ougham, H.; Prats, E. The hypersensitive response; The centenary is upon us but how much do we know? J. Exp. Bot. 2008, 59, 501-520. [CrossRef] [PubMed]

43. Schnathorst, W.C. Environmental relationships in the powdery mildews. Annu. Rev. Phytopathol. 1965, 3, 343-366. [CrossRef]

44. Yarwood, C.E. Powdery mildews. Bot. Rev. 1957, 23, 235-301. [CrossRef]

45. Plumb, R.T.; Turner, R.H. Scanning electron microscopy of Erysiphe graminis. Trans. Br. Mycol. Soc. 1972, 59, 149-150, IN20-IN21. [CrossRef]

46. Grove, G.G. Meteorological factors affecting airborne conidia concentrations and the latent period of Podosphaera clandestina on sweet cherry. Plant Dis. 1998, 82, 741-746. [CrossRef]

47. Adams, G.C., Jr.; Gottwald, T.R.; Leach, C.M. Environmental factors initiating liberation of conidia of powdery mildews. Phytopathology 1986, 76, 1239-1245. [CrossRef]

48. Byrne, J.M.; Hausbeck, M.K.; Shaw, B.D. Factors affecting concentrations of airborne conidia of Oidium sp. among poinsettias in a greenhouse. Plant Dis. 2000, 84, 1089-1095. [CrossRef]

49. Peries, O.S. Studies on strawberry mildew, caused by Sphaerotheca macularis (Wallr. ex Fries) Jaczewski* II. Host-parasite relationships on foliage of strawberry varieties. Ann. Appl. Biol. 1962, 50, 225-233. [CrossRef]

50. Hermansen, J.E.; Torp, U.; Prahm, L.P. Studies of transport of live spores of cereal mildew and rust fungi across the North Sea. Grana 1978, 17, 41-46. [CrossRef]

51. Braun, U.; Cook, R.T.A.; Inman, A.J.; Shin, H.D. The taxonomy of the powdery mildew fungi. In The Powdery Mildews: A Comprehensive Treatise; Bélanger, R.R., Bushnell, W.R., Dik, A.J., Carver, T.L.W., Eds.; American Phytopathological Society (APS Press): St. Paul, MN, USA, 2002; pp. 13-55.

52. Braun, U. A monograph of the Erysiphales (powdery mildews). Beih. Nova Hedwig. 1987, 89, 700.

53. Schnathorst, W.C. Spread and life cycle of the lettuce powdery mildew fungus. Phytopathology 1959, 49, 464-468.

54. Grove, G.G. Perennation of Uncinula necator in vineyards of Eastern Washington. Plant Dis. 2004, 88, 242-247. [CrossRef] [PubMed]

55. Rumbolz, J.; Gubler, W.D. Susceptibility of grapevine buds to infection by powdery mildew Erysiphe necator. Plant Pathol. 2005, 54, 535-548. [CrossRef] 
56. Takamatsu, S.; Ito, H.; Shiroya, Y.; Kiss, L.; Heluta, V. First comprehensive phylogenetic analysis of the genus Erysiphe (Erysiphales, Erysiphaceae) I. The Microsphaera lineage. Mycologia 2015, 107, 475-489. [CrossRef]

57. Falloon, R.E.; Viljanen-Rollinson, S.L.H. Powdery mildew. In Compendium of Pea Diseases and Pests; Kraft, J.M., Pfleger, F.L., Eds.; American Phytopathological Society: St. Paul, MN, USA, 2001; pp. 28-29.

58. Ondřej, M.; Dostálová, R.; Odstrčilová, L. Response of Pisum sativum germplasm resistant to Erysiphe pisi to inoculation with Erysiphe baeumleri, a new pathogen of pea. Plant Prot. Sci. 2005, 41, 95-103. [CrossRef]

59. Attanayake, R.N.; Glawe, D.A.; Dugan, F.M.; Chen, W. Erysiphe trifolii causing powdery mildew of lentil (Lens culinaris). Plant Dis. 2009, 93, 797-803. [CrossRef]

60. Attanayake, R.N.; Glawe, D.A.; McPhee, K.E.; Dugan, F.M.; Chen, W. Erysiphe trifolii-A newly recognized powdery mildew pathogen of pea. Plant Pathol. 2010, 59, 712-720. [CrossRef]

61. Takamatsu, S.; Shin, H.D.; Paksiri, U.; Limkaisang, S.; Taguchi, Y.; Binh, N.T.; Sato, Y. Two Erysiphe species associated with recent outbreak of soybean powdery mildew: Results of molecular phylogenetic analysis based on nuclear rDNA sequences. Mycoscience 2002, 43, 333-341. [CrossRef]

62. Kasettranan, W.; Somta, P.; Srinives, P. Mapping of Quantitative Trait Loci Controlling Powdery Mildew Resistance in Mungbean (Vigna radiata (L.) Wilczek). J. Crop Sci. Biotechnol. 2010, 13, 155-161. [CrossRef]

63. Jun, T.H.; Mian, M.A.R.; Kang, S.T.; Michel, A.P. Genetic mapping of the powdery mildew resistance gene in soybean PI 567301B Theor. Appl. Genet. 2012, 125, 1159-1168. [CrossRef] [PubMed]

64. Dunleavy, J.M. Soybean Seed Yield Losses Caused by Powdery Mildew 1. Crop Sci. 1978, 18, 337-339. [CrossRef]

65. Chaitieng, B.; Kaga, A.; Han, O.K.; Wang, X.W.; Wongkaew, S.; Laosuwan, P.; Tomooka, N.; Vaughan, D.A. Mapping a new source of resistance to powdery mildew in mungbean. Plant Breed. 2002, 121, 521-525. [CrossRef]

66. Warkentin, T.D.; Rashid, K.Y.; Xue, A.G. Fungicidal control of powdery mildew in field pea. Can. J. Plant Sci. 1996, 76, 933-935. [CrossRef]

67. Macleod, W.; Basandrai, A.; Basandrai, D.; Bakr, A.; Sandhu, J.S. Integrated foliar diseases management of legumes. In Proceedings of the International Conference on Grain Legumes: Quality Improvement, Value Addition and Trade, Kanpur, India, 14-16 February 2009; pp. 143-161.

68. Lampson, M.A.; Kapoor, T.M. Unraveling cell division mechanisms with small-molecule inhibitors. Nat. Chem. Biol. 2006, 2, 19-27. [CrossRef]

69. Richmond, D.V.; Phillips, A. The effect of benomyl and carbendazim on mitosis in hyphae of Botrytis cinerea Pers. ex Fr. and roots of Allium cepa L. Pestic. Biochem. Physiol. 1975, 5, 367-379. [CrossRef]

70. Hippe, S.; Giesen, U. The effect of triadimenol on the cytology and growth of sensitive and resistant strains of Ustilago avenue. Ann. Appl. Biol. 1988, 112, 79-90. [CrossRef]

71. Brown, I.F.; Taylor, H.M.; Hall, H.R. EL-222, a new fungicide with eradicative activity. Proc. Am. Phytopathol. Soc. 1975, $2,31$.

72. Huggenberger, F.; Collins, M.A.; Skylakakis, G. Decreased sensitivity of Sphaerotheca fuliginea to fenarimol and other ergosterolbiosynthesis inhibitors. Crop Prot. 1984, 3, 137-149. [CrossRef]

73. Baloch, R.I.; Mercer, E.I.; Wiggins, T.E.; Baldwin, B.C. Inhibition of ergosterol biosynthesis in Saccharomyces cerevisiae and Ustilago maydis by tridemorph, fenpropimorph and fenpropidin. Phytochemistry 1984, 23, 2219-2226. [CrossRef]

74. Caux, P.Y.; Kent, R.A.; Fan, G.T.; Stephenson, G.L. Environmental fate and effects of chlorothalonil: A Canadian perspective. Crit. Rev. Environ. Sci. Technol. 1996, 26, 45-93. [CrossRef]

75. Barak, E.; Edgington, L.V. Cross-resistance of botrytis cinerea to captan, thiram, chlorothalonil, and related fungicides. Can. J. Plant Pathol. 1984, 6, 318-320. [CrossRef]

76. Bélanger, R.R.; Labbé, C. Control of powdery mildews without chemicals: Prophylactic and biological alternatives for horticultural crops. In The Powdery Mildews: A Comprehensive Treatise; Bélanger, R.R., Bushnell, W.R., Dik, A.J., Carver, T.L.W., Eds.; American Phytopathological Society (APS Press): St. Paul, MN, USA, 2002; pp. 256-267.

77. Pandey, M.K.; Sarma, B.K.; Singh, D.P.; Singh, U.P. Biochemical investigations of sclerotial exudates of Sclerotium rolfsii and their antifungal activity. J. Phytopathol. 2007, 155, 84-89. [CrossRef]

78. Segarra, G.; Reis, M.; Casanova, E.; Trillas, M.I. Control of powdery mildew (Erysiphe polygoni) in tomato by foliar applications of compost tea. J. Plant Pathol. 2009, 683-689.

79. Patil, N.B.; Zacharia, S.; Kumari, M. Eco-friendly management of downy mildew of Garden pea (Pisum sativum L.). Ecol. Environ. Conserv. 2016, 22, 691-694. [CrossRef]

80. Maurya, S.; Singh, D.P.; Srivastava, J.S.; Singh, V.P. Effect of some plant extracts on pea powdery mildew (Erysiphe pisi). Ann. Plant Prot. Sci. 2004, 12, 288-291.

81. Prithiviraj, B.; Singh, U.P.; Manickam, M.; Srivastava, J.S.; Ray, A.B. Antifungal activity of bergenin, a constituent of Flueggea microcarpa. Plant Pathol. 1997, 46, 224-228. [CrossRef]

82. Prithiviraj, B.; Singh, U.P.; Singh, K.P.; Plank-Schumacher, K. Field evaluation of ajoene, a constituent of garlic (Allium sativum) and neemazal, a product of neem (Azadirachta indica) for the control of powdery mildew (Erysiphe pisi) of pea (Pisum sativum)/Bewertung von Ajoen, einem Inhaltsstoff des Knoblauchs (Allium sativum), und Neemazal, einem Produkt aus Niem (Azadirachta indica), zur Bekämpfung des Echten Mehltaus (Erysiphe pisi) an Erbsen (Pisum sativum) im Freiland. Z. Pflanzenkrankh. Pflanzenschutz J. Plant Dis. Prot. 1998, 105, 274-278. 
83. Vechet, L.; Martinkova, J.; Sindelarova, M.; Burketova, L. Compounds of natural origin inducing winter wheat resistance to powdery mildew (Blumeria graminis f. sp. tritici). Plant Soil Environ. 2005, 51, 468.

84. Vimala, R.; Suriachandraselvan, M. Induced resistance in bhendi against powdery mildew by foliar application of salicylic acid. $J$. Biopestic. 2009, 2, 111-114.

85. Faoro, F.; Maffi, D.; Cantu, D.; Iriti, M. Chemical-induced resistance against powdery mildew in barley: The effects of chitosan and benzothiadiazole. Biocontrol 2008, 53, 387-401. [CrossRef]

86. Kiss, L. A review of fungal antagonists of powdery mildews and their potential as biocontrol agents. Pest Manag. Sci. 2003, 59, 475-483. [CrossRef]

87. Paulitz, T.C.; Bélanger, R.R. Biological control in greenhouse systems. Annu. Rev. Phytopathol. 2001, 39, 103-133. [CrossRef] [PubMed]

88. Elad, Y. Biological control of foliar pathogens by means of Trichoderma harzianum and potential modes of action. Crop Prot. 2000 19, 709-714. [CrossRef]

89. Duzan, H.M.; Mabood, F.; Zhou, X.; Souleimanov, A.; Smith, D.L. Nod factor induces soybean resistance to powdery mildew. Plant Physiol. Biochem. 2005, 43, 1022-1030. [CrossRef]

90. Smigielski, L.; Laubach, E.M.; Pesch, L.; Glock, J.M.L.; Albrecht, F.; Slusarenko, A.; Panstruga, R.; Kuhn, H. Nodulation induces systemic resistance of Medicago truncatula and Pisum sativum against erysiphe pisi and primes for powdery mildew-triggered salicylic acid accumulation. Mol. Plant-Microbe Interact. 2019, 32, 1243-1255. [CrossRef]

91. Parniske, M. Arbuscular mycorrhiza: The mother of plant root endosymbioses. Nat. Rev. Microbiol. 2008, 6, 763-775. [CrossRef]

92. Ruiz-Lozano, J.M.; Gianinazzi, S.; Gianinazzi-Pearson, V. Genes involved in resistance to powdery mildew in barley differentially modulate root colonization by the mycorrhizal fungus Glomus mosseae. Mycorrhiza 1999, 9, 237-240. [CrossRef]

93. Mustafa, G.; Khong, N.G.; Tisserant, B.; Randoux, B.; Fontaine, J.; Magnin-Robert, M.; Reignault, P.; Sahraoui, A.L.H. Defence mechanisms associated with mycorrhiza-induced resistance in wheat against powdery milde. Funct. Plant Biol. 2017, 44, 443-454 [CrossRef]

94. Singh, D.P.; Srivastava, J.S.; Bahadur, A.; Singh, U.P.; Singh, S.K. Arbuscular mycorrhizal fungi induced biochemical changes in pea (Pisum sativum) and their effect on powdery mildew (Erysiphe pisi)/Arbusculäre Mykorrhizapilze induzieren biochemische Veränderungen in Erbsen (Pisum sativum) und ihre Wirkung auf Echten Mehl. Z. Pflanzenkrankh. Pflanzenschutz J. Plant Dis. Prot. 2004, 111, 266-272.

95. Stein, E.; Molitor, A.; Kogel, K.H.; Waller, F. Systemic resistance in Arabidopsis conferred by the mycorrhizal fungus Piriformospora indica requires jasmonic acid signaling and the cytoplasmic function of NPR1. Plant Cell Physiol. 2008, 49, 1747-1751. [CrossRef]

96. Mustafa, G.; Randoux, B.; Tisserant, B.; Fontaine, J.; Magnin-Robert, M.; Lounès-Hadj Sahraoui, A.; Reignault, P. Phosphorus supply, arbuscular mycorrhizal fungal species, and plant genotype impact on the protective efficacy of mycorrhizal inoculation against wheat powdery mildew. Mycorrhiza 2016, 26, 685-697. [CrossRef]

97. Larsen, J.; Yohalem, D. Interactions between mycorrhiza and powdery mildew of cucumber. Mycol. Prog. 2004, 3, 123-128. [CrossRef]

98. Liu, Y.; Feng, X.; Gao, P.; Li, Y.; Christensen, M.J.; Duan, T. Arbuscular mycorrhiza fungi increased the susceptibility of Astragalus adsurgens to powdery mildew caused by Erysiphe pisi. Mycology 2018, 9, 223-232. [CrossRef] [PubMed]

99. Hafez, Y.M.; Attia, K.A.; Kamel, S.; Alamery, S.F.; El-Gendy, S.; Al-Doss, A.A.; Mehiar, F.; Ghazy, A.I.; Ibrahim, E.I.; Abdelaal, K.A.A. Bacillus subtilis as a bio-agent combined with nano molecules can control powdery mildew disease through histochemical and physiobiochemical changes in cucumber plants. Physiol. Mol. Plant Pathol. 2020, 111, 101489. [CrossRef]

100. García-Gutiérrez, L.; Zeriouh, H.; Romero, D.; Cubero, J.; de Vicente, A.; Pérez-García, A. The antagonistic strain B acillus subtilis UMAF 6639 also confers protection to melon plants against cucurbit powdery mildew by activation of jasmonate-and salicylic acid-dependent defence responses. Microb. Biotechnol. 2013, 6, 264-274. [CrossRef]

101. Gao, X.; Gong, Y.; Huo, Y.; Han, Q.; Kang, Z.; Huang, L. Endophytic Bacillus subtilis strain E1R-J is a promising biocontrol agent for wheat powdery mildew. Biomed Res. Int. 2015, 2015. [CrossRef]

102. Tanaka, K.; Fukuda, M.; Amaki, Y.; Sakaguchi, T.; Inai, K.; Ishihara, A.; Nakajima, H. Importance of prumycin produced by Bacillus amyloliquefaciens SD-32 in biocontrol against cucumber powdery mildew disease. Pest Manag. Sci. 2017, 73, 2419-2428. [CrossRef]

103. Hafez, Y.M.; El-Nagar, A.S.; Elzaawely, A.A.; Kamel, S.; Maswada, H.F. Biological control of Podosphaera xanthii the causal agent of squash powdery mildew disease by upregulation of defense-related enzymes. Egypt. J. Biol. Pest Control 2018, 28, 1-8. [CrossRef]

104. Janousek, C.N.; Lorber, J.D.; Gubler, W.D. Combination and rotation of bacterial antagonists to control powdery mildew on pumpkin. J. Plant Dis. Prot. 2009, 116, 260-262. [CrossRef]

105. Raguchander, T.; Prabakar, K.; Samiyappan, R. Held evaluation of Pseudomonas fluorescens and Bacillus subtius on the management of Cercospora leaf spot and powdery mildew in urdbean. Legum. Res. Int. J. 2005, 28, 137-139.

106. Singh, U.P.; Prithiviraj, B.; Singh, K.P.; Sarma, B.K. Control of powdery mildew (Erysiphe pisi) of pea (Pisum sativum) by combined application of plant growth-promoting rhizobacteria and NeemazalTM. Z. Pflanzenkrankh. Pflanzenschutz 2000, 107, 59-66.

107. Ghebrial, E.; El-Abeid, S.; Aref, E. Bio-Control of Chamomile Powdery Mildew Using Cyanobacteria and Some Antagonistic Microorganisms. Egypt. J. Phytopathol. 2019, 47, 53-77. [CrossRef]

108. Whipps, J.M. Microbial interactions and biocontrol in the rhizosphere. J. Exp. Bot. 2001, 52, 487-511. [CrossRef] 
109. Bélanger, R.R.; Labbé, C.; Lefebvre, F.; Teichmann, B. Mode of action of biocontrol agents: All that glitters is not gold. Can. J. Plant Pathol. 2012, 34, 469-478. [CrossRef]

110. Laur, J.; Ramakrishnan, G.B.; Labbé, C.; Lefebvre, F.; Spanu, P.D.; Bélanger, R.R. Effectors involved in fungal-fungal interaction lead to a rare phenomenon of hyperbiotrophy in the tritrophic system biocontrol agent-powdery mildew-plant. New Phytol. 2018, 217, 713-725. [CrossRef]

111. Considine, M.J.; Siddique, K.H.M.; Foyer, C.H. Nature's pulse power: Legumes, food security and climate change. J. Exp. Bot. 2017, 68, 1815-1818. [CrossRef]

112. Stagnari, F.; Maggio, A.; Galieni, A.; Pisante, M. Multiple benefits of legumes for agriculture sustainability: An overview. Chem. Biol. Technol. Agric. 2017, 4, 2. [CrossRef]

113. Siddique, K.H.M.; Johansen, C.; Turner, N.C.; Jeuffroy, M.H.; Hashem, A.; Sakar, D.; Gan, Y.; Alghamdi, S.S. Innovations in agronomy for food legumes. A review. Agron. Sustain. Dev. 2012, 32, 45-64. [CrossRef]

114. Foyer, C.H.; Lam, H.M.; Nguyen, H.T.; Siddique, K.H.M.; Varshney, R.K.; Colmer, T.D.; Cowling, W.; Bramley, H.; Mori, T.A.; Hodgson, J.M.; et al. Neglecting legumes has compromised human health and sustainable food production. Nat. Plants 2016, 2, 1-10. [CrossRef] [PubMed]

115. Eckardt, N.A. Plant disease susceptibility genes? Plant Cell 2002, 14, 1983-1986. [CrossRef] [PubMed]

116. Pavan, S.; Jacobsen, E.; Visser, R.G.F.; Bai, Y. Loss of susceptibility as a novel breeding strategy for durable and broad-spectrum resistance. Mol. Breed. 2010, 25, 1. [CrossRef]

117. De Almeida Engler, J.; Favery, B.; Engler, G.; Abad, P. Loss of susceptibility as an alternative for nematode resistance. Curr. Opin. Biotechnol. 2005, 16, 112-117. [CrossRef]

118. Boyd, L.A.; Smith, P.H.; Foster, E.M.; Brown, J.K.M. The effects of allelic variation at the Mla resistance locus in barley on the early development of Erysiphe graminis f. sp. hordei and host responses. Plant J. 1995, 7, 959-968. [CrossRef]

119. Jørgensen, J.H. Genetics of powdery mildew resistance in barley. Critical Reviews in. Plant Sci. 1994, 13, 97-119.

120. Halterman, D.; Zhou, F.; Wei, F.; Wise, R.P.; Schulze-Lefert, P. The MLA6 coiled-coil, NBS-LRR protein confers AvrMla6-dependent resistance specificity to Blumeria graminis f. sp. hordei in barley and wheat. Plant J. 2001, 25, 335-348. [CrossRef]

121. Halterman, D.A.; Wise, R.P. A single-amino acid substitution in the sixth leucine-rich repeat of barley MLA6 and MLA13 alleviates dependence on RAR1 for disease resistance signaling. Plant J. 2004, 38, 215-226. [CrossRef]

122. Jørgensen, I.H. Discovery, characterization and exploitation of Mlo powdery mildew resistance in barley. Euphytica 1992, 63, 141-152. [CrossRef]

123. Büschges, R.; Hollricher, K.; Panstruga, R.; Simons, G.; Wolter, M.; Frijters, A.; Van Daelen, R.; Van der Lee, T.; Diergaarde, P.; Groenendijk, J.; et al. The barley Mlo gene: A novel control element of plant pathogen resistance. Cell 1997, 88, 695-705. [CrossRef]

124. Devoto, A.; Hartmann, H.A.; Piffanelli, P.; Elliott, C.; Simmons, C.; Taramino, G.; Goh, C.S.; Cohen, F.E.; Emerson, B.C.; SchulzeLefert, P.; et al. Molecular phylogeny and evolution of the plant-specific seven-transmembrane MLO family. J. Mol. Evol. 2003, 56, 77-88. [CrossRef] [PubMed]

125. Devoto, A.; Piffanelli, P.; Nilsson, I.M.; Wallin, E.; Panstruga, R.; Von Heijne, G.; Schulze-Lefert, P. Topology, subcellular localization, and sequence diversity of the Mlo family in plants. J. Biol. Chem. 1999, 274, 34993-35004. [CrossRef] [PubMed]

126. Chen, Z.; Hartmann, H.A.; Wu, M.-J.; Friedman, E.J.; Chen, J.-G.; Pulley, M.; Schulze-Lefert, P.; Panstruga, R.; Jones, A.M. Expression analysis of the AtMLO gene family encoding plant-specific seven-transmembrane domain proteins. Plant Mol. Biol. 2006, 60, 583-597. [CrossRef] [PubMed]

127. Feechan, A.; Jermakow, A.M.; Torregrosa, L.; Panstruga, R.; Dry, I.B. Identification of grapevine MLO gene candidates involved in susceptibility to powdery mildew. Funct. Plant Biol. 2008, 35, 1255-1266. [CrossRef]

128. Zhou, S.J.; Jing, Z.; Shi, J.L. Genome-wide identification, characterization, and expression analysis of the MLO gene family in Cucumis sativus. Genet. Mol. Res. 2013, 12, 6565-6578. [CrossRef]

129. Chen, Y.; Wang, Y.; Zhang, H. Genome-wide analysis of the mildew resistance locus o ('MLO') gene family in tomato ('Solanum lycopersicum' L.). Plant Omics 2014, 7, 87-93.

130. Iovieno, P.; Bracuto, V.; Pavan, S.; Lotti, C.; Ricciardi, L.; Andolfo, G. Identification and functional inference on the MLO-family in viridiplantae. J. Plant Pathol. 2016, 98, 587-594. [CrossRef]

131. Rispail, N.; Rubiales, D. Genome-wide identification and comparison of legume MLO gene family. Sci. Rep. 2016, 6, 1-12. [CrossRef]

132. Wolter, M.; Hollricher, K.; Salamini, F.; Schulze-Lefert, P. The mlo resistance alleles to powdery mildew infection in barley trigger a developmentally controlled defence mimic phenotype. Mol. Gen. Genet. 1993, 239, 122-128. [CrossRef]

133. Peterhänsel, C.; Freialdenhoven, A.; Kurth, J.; Kolsch, R.; Schulze-Lefert, P. Interaction analyses of genes required for resistance responses to powdery mildew in barley reveal distinct pathways leading to leaf cell death. Plant Cell 1997, 9, 1397-1409. [CrossRef]

134. Kusch, S.; Panstruga, R. Mlo-based resistance: An apparently universal "weapon" to defeat powdery mildew disease. Mol. Plant-Microbe Interact. 2017, 30, 179-189. [CrossRef] [PubMed]

135. Sun, S.; Deng, D.; Duan, C.; Zong, X.; Xu, D.; He, Y.; Zhu, Z. Two novel er1 alleles conferring powdery mildew (Erysiphe pisi) resistance identified in a worldwide collection of pea (Pisum sativum L.) germplasms. Int. J. Mol. Sci. 2019, 20, 5071. [CrossRef] [PubMed] 
136. Sun, S.; Deng, D.; Wang, Z.; Duan, C.; Wu, X.; Wang, X.; Zong, X.; Zhu, Z. A novel er1 allele and the development and validation of its functional marker for breeding pea (Pisum sativum L.) resistance to powdery mildew. Theor. Appl. Genet. 2016, 129, 909-919. [CrossRef] [PubMed]

137. Wang, Z.; Fu, H.; Sun, S.; Duan, C.; Wu, X.; Yang, X.; Zhu, Z. Identification of powdery mildew resistance gene in pea line X9002. ACTA Agron. Sin. 2015, 41, 515-523. [CrossRef]

138. Sudheesh, S.; Lombardi, M.; Leonforte, A.; Cogan, N.O.I.; Materne, M.; Forster, J.W.; Kaur, S. Consensus Genetic Map Construction for Field Pea (Pisum sativum L.), Trait Dissection of Biotic and Abiotic Stress Tolerance and Development of a Diagnostic Marker for the er1 Powdery Mildew Resistance Gene. Plant Mol. Biol. Report. 2015, 33, 1391-1403. [CrossRef]

139. Ma, Y.; Coyne, C.J.; Main, D.; Pavan, S.; Sun, S.; Zhu, Z.; Zong, X.; Leitão, J.; McGee, R.J. Development and validation of breeder-friendly KASPar markers for er1, a powdery mildew resistance gene in pea (Pisum sativum L.). Mol. Breed. 2017, $37,151$. [CrossRef]

140. Pavan, S.; Schiavulli, A.; Appiano, M.; Miacola, C.; Visser, R.G.F.; Bai, Y.; Lotti, C.; Ricciardi, L. Identification of a complete set of functional markers for the selection of er1 powdery mildew resistance in Pisum sativum L. Mol. Breed. 2013, 31, 247-253. [CrossRef]

141. Ambrose, M.J. Screening for field resistance to Powdery Mildew (Eyrsiphe polygoni D. C.) in the JI Pisum Collection. Pisum Genet 2009, 41, 40-43.

142. Santo, T.; Rashkova, M.; Alabaça, C.; Leitão, J. The ENU-induced powdery mildew resistant mutant pea (Pisum sativum L.) lines $\mathrm{S}$ (er1mut1) and F(er1mut2) harbour early stop codons in the PsMLO1 gene. Mol. Breed. 2013, 32, 723-727. [CrossRef]

143. Fu, H.; Sun, S.; Zhu, Z.; Duan, C.; Yang, X. Phenotypic and genotypic identification of powdery mildew resistance in pea cultivars or lines from Canada. J. Plant Genet. Resour. 2014, 15, 1028-1033.

144. Sun, S.; Fu, H.; Wang, Z.; Duan, C.; Zong, X.; Zhu, Z. Discovery of a novel er1 allele conferring powdery mildew resistance in Chinese Pea (Pisum sativum L.) landraces. PLoS ONE 2016, 11, e0147624. [CrossRef] [PubMed]

145. Sun, S.; Wang, Z.; Fu, H.; Duan, C.; Wang, X.; Zhu, Z. Resistance to powdery mildew in the pea cultivar Xucai 1 is conferred by the gene er1. Crop J. 2015, 3, 489-499. [CrossRef]

146. Binagwa, P.H.; Traore, S.M.; Egnin, M.; Bernard, G.C.; Ritte, I.; Mortley, D.; Kamfwa, K.; He, G.; Bonsi, C. Genome-Wide Identification of Powdery Mildew Resistance in Common Bean (Phaseolus vulgaris L.). Front. Genet. 2021, 12, 673069. [CrossRef] [PubMed]

147. Deshmukh, R.; Singh, V.K.; Singh, B.D. Comparative phylogenetic analysis of genome-wide Mlo gene family members from Glycine max and Arabidopsis thaliana. Mol. Genet. Genom. 2014, 289, 345-359. [CrossRef] [PubMed]

148. Shen, Q.; Zhao, J.; Du, C.; Xiang, Y.; Cao, J.; Qin, X. Genome-scale identification of MLO domain-containing genes in soybean (Glycine max L. Merr.). Genes Genet. Syst. 2012, 87, 89-98. [CrossRef]

149. Chankaew, S.; Somta, P.; Isemura, T.; Tomooka, N.; Kaga, A.; Vaughan, D.A.; Srinives, P. Quantitative trait locus mapping reveals conservation of major and minor loci for powdery mildew resistance in four sources of resistance in mungbean [Vigna radiata (L.) Wilczek]. Mol. Breed. 2013, 32, 121-130. [CrossRef]

150. Parkhi, V.; Bhattacharya, A.; Char, B. Multiomics Technologies and Genetic Modification in Plants: Rationale, Opportunities and Reality. In Omics Technologies for Sustainable Agriculture and Global Food Security (Vol II); Kumar, A., Kumar, R., Shukla, P., Patel, H.K., Eds.; Springer: Singapore, 2021; Volume II, pp. 313-328.

151. Prats, E.; Llamas, M.J.; Rubiales, D. Characterization of resistance mechanisms to Erysiphe pisi in Medicago truncatula. Phytopathology 2007, 97, 1049-1053. [CrossRef]

152. Yaege, J.R.; Stuteville, D.L. Reactions of accessions in the annual Medicago core germ plasm collection to Erysiphe pisi. Plant Dis. 2002, 86, 312-315. [CrossRef]

153. Ameline-Torregrosa, C.; Cazaux, M.; Danesh, D.; Chardon, F.; Cannon, S.B.; Esquerré-Tugayé, M.T.; Dumas, B.; Young, N.D.; Samac, D.A.; Huguet, T.; et al. Genetic dissection of resistance to anthracnose and powdery mildew in Medicago truncatula. Mol. Plant-Microbe Interact. 2008, 21, 61-69. [CrossRef]

154. Yang, S.; Tang, F.; Caixeta, E.T.; Zhu, H. Epigenetic regulation of a powdery mildew resistance gene in medicago truncatula. Mol. Plant 2013, 6, 2000-2003. [CrossRef] [PubMed]

155. Lohnes, D.G.; Wagner, R.E.; Bernard, R.L. Soybean genes Rj2, Rmd, and Rps2 in linkage group 19. J. Hered. 1993, 84, $109-111$. [CrossRef]

156. Polzin, K.M.; Lohnes, D.G.; Nickell, C.D.; Shoemaker, R.C. Integration of rps2, rmd, and rj2 into linkage group j of the soybean molecular map. J. Hered. 1994, 85, 300-303. [CrossRef]

157. Lohnes, D.G.; Nickell, C.D. Effects of powdery mildew alleles Rmd-c, Rmd and rmd on yield and other characteristics in soybean. Plant Dis. 1994, 78, 299-301. [CrossRef]

158. Kang, S.T.; Rouf Mian, M.A. Genetic map of the powdery mildew resistance gene in soybean PI 243540. Genome 2010, 53, 400-405. [CrossRef] [PubMed]

159. Shoemaker, R.C.; Schlueter, J.; Doyle, J.J. Paleopolyploidy and gene duplication in soybean and other legumes. Curr. Opin. Plant Biol. 2006, 9, 104-109. [CrossRef]

160. Walling, J.G.; Shoemaker, R.; Young, N.; Mudge, J.; Jackson, S. Chromosome-level homeology in paleopolyploid soybean (Glycine $\max$ ) revealed through integration of genetic and chromosome maps. Genetics 2006, 172, 1893-1900. [CrossRef] 
161. Deshmukh, R.; Singh, V.K.; Singh, B.D. Comparative analysis of genome-wide Mlo gene family in Cajanus cajan and Phaseolus vulgaris. Genetica 2016, 144, 229-241. [CrossRef]

162. Polanco, C.; Sáenz De Miera, L.E.; Bett, K.; De La Vega, M.P. A genome-wide identification and comparative analysis of the lentil MLO genes. PLoS ONE 2018, 13, e0194945. [CrossRef]

163. Yundaeng, C.; Somta, P.; Chen, J.; Yuan, X.; Chankaew, S.; Srinives, P.; Chen, X. Candidate gene mapping reveals VrMLO12 (MLO Clade II) is associated with powdery mildew resistance in mungbean (Vigna radiata [L.] Wilczek). Plant Sci. 2020, $298,110594$. [CrossRef]

164. Traore, S.M.; Han, S.; Binagwa, P.; Xu, W.; Chen, X.; Liu, F.; He, G. Genome-wide identification of mlo genes in the cultivated peanut (Arachis hypogaea L.). Euphytica 2021, 217, 61. [CrossRef]

165. Bolay, A.; Braun, U.; Delhey, R.; Kummer, V.; Piatek, M.; Wołczańska, A. Erysiphe deutziae-A new epidemic spread in Europe. Cryptogam. Mycol. 2005, 26, 293-298.

166. Dynowska, M. A comparison of urban and suburban occurrence of Erysiphales with special emphasis on degree of host infection Acta Soc. Bot. Pol. 1994, 63, 341-344. [CrossRef]

167. Smith, J.M. A comment on the Red Queen. Am. Nat. 1976, 110, 325-330. [CrossRef]

168. Cobos, M.J.; Satovic, Z.; Rubiales, D.; Fondevilla, S. Er3 gene, conferring resistance to powdery mildew in pea, is located in pea LGIV. Euphytica 2018, 214. [CrossRef]

169. Jha, A.B.; Gali, K.K.; Alam, Z.; Lachagari, V.B.R.; Warkentin, T.D. Potential application of genomic technologies in breeding for fungal and oomycete disease resistance in pea. Agronomy 2021, 11, 1260. [CrossRef]

170. Kreplak, J.; Madoui, M.A.; Cápal, P.; Novák, P.; Labadie, K.; Aubert, G.; Bayer, P.E.; Gali, K.K.; Syme, R.A.; Main, D.; et al. A reference genome for pea provides insight into legume genome evolution. Nat. Genet. 2019, 51, 1411-1422. [CrossRef]

171. Rogers, S.O.; Bendich, A.J. Extraction of DNA from milligram amounts of fresh, herbarium and mummified plant tissues. Plant Mol. Biol. 1985, 5, 69-76. [CrossRef]

172. Sulima, A.S.; Zhukov, V.A.; Afonin, A.A.; Zhernakov, A.I.; Tikhonovich, I.A.; Lutova, L.A. Selection Signatures in the First Exon of Paralogous Receptor Kinase Genes from the Sym2 Region of the Pisum sativum L. Genome. Front. Plant Sci. $2017,8,1957$. [CrossRef]

173. Corpet, F. Multiple sequence alignment with hierarchical clustering. Nucleic Acids Res. 1988, 16, 10881-10890. [CrossRef] 